\title{
The Study of Customer Experience Design and Optimization of Shopping Website: Case Analysis of Amazon in China
}

\author{
Songming Yang ${ }^{1}$ \\ ${ }^{1}$ University of Southampton, Southampton, England \\ Correspondence: Songming Yang, University of Southampton, Southampton, England.
}

Received: May 20, 2019

Accepted: June 4, 2019

Online Published: June 6, 2019

doi:10.20849/abr.v4i2.591

URL: https://doi.org/10.20849/abr.v4i2.591

\begin{abstract}
Customer experience design plays an important role in the development and optimization of shopping websites (Menon and Kahn, 2002). To satisfy the increasing demands of customers and to attract additional loyal customers, customer experience design is increasingly valued by e-commerce enterprises (Ribbink et al., 2004). Since 1995, Amazon has become the leader in online shopping (Amblee and Bui, 2011). Therefore, the study of Amazon's customer experience design can provide successful experience and offer valuable information for other shopping sites.

This project adopts textual analysis and case study methods. Firstly, it introduces the concept, importance, and influencing factors of customer experience and shopping website's customer experience design. Furthermore, the project provides a detailed description of Amazon China's current development situation in the Chinese market. Secondly, comparing Amazon China with its major competitors highlights the differences in customer experience design in terms of product, design, service, and marketing, while listing the pros and cons of Amazon's customer experience. Finally, the project summarizes the importance of customer experience for shopping website development and proposes the optimization and improvement suggestions to Amazon China.
\end{abstract}

Keywords: Amazon China, online shopping, customer experience design, optimization, customer service

\section{Introduction}

Due to the global appeal of the Internet and the convenience of online shopping, an increasing number of people are choosing to engage in online shopping (Javadi et al., 2012). According to Gandhi (2016), reports indicate that the number of global Internet users reached about 3.2 billion in June 2016 and the number will continue to increase in the next 3-5 years. $\mathrm{Li}$ (2015) states that in China, which is the largest consumer market in the world, 688 million people made use of online shopping in 2015. This indicates that the growth potential of online shopping in the future is huge. Customer experience has become a significant factor in online shopping. Different people have different understandings of customer experience, but generally speaking, it is the customer's feeling when they purchase a product; in the case of a shopping website, customer experience encompasses the entire shopping process (Park, 2003).

Because of the expansion and development of online shopping over the past few years, customer expectation of shopping sites is increasing. Thus, customer experience is an important component of online shopping sites, which influence sustainable development and the future living space. The question is whether the shopping website can retain existing customers in the marketplace; attract new customers, and increase customer loyalty and satisfaction. (Ali etc, 2016). Customer demand rises from the initial shopping to the experience demand and company design changes from non-customer experience to view customers as the base of the design, which shows the development of customer experience design and optimization is a very complicated process (Myers et al., 2016). How to provide customers with a comfortable and satisfying customer experience while continuing to improve customer experience design is an important issue that all shopping websites need to address and consider. How does one provide a comfortable and satisfying customer experience to the customer, while continuing to improve the customer experience design, which is an important issue that needs to be addressed and considered with regard to all shopping sites? How to provide customers with a comfortable and satisfying customer experience while continuing to improve customer experience design is an important issue that all shopping websites need to address and consider. 
Since 1995, Amazon has become a recognized world leader in the field of electronic commerce (Wang, 2016). Amazon's success is not accidental, but is a direct result of a strong customer shopping experience, as its customer shopping experience provides a successful model for subsequent shopping sites (Yoon et al., 2013). Why does Amazon occupy the dominant position in the world market, while the situation in the Chinese market is the opposite? In the first quarter of 2016, Amazon sales accounted for only $1.3 \%$ of the Chinese market (Figure 1) compared with a similar B2C shopping website, Tmall, which accounted for $61.4 \%$ (Havinga et al., 2016). Although Amazon's online shopping system has achieved global success, it encounters obstacles in the Chinese market. Moreover, in the Chinese market, electronic commerce advertising is ubiquitous, and thus it is difficult to understand why Amazon does not enjoy great success. Amazon's emphasis on customer experience is a supreme principle, but it encounters difficulties when it faces the Chinese market. Thus, a study is needed to conduct and find out the answers and solutions. Through research on customer experience design and Amazon's marketing strategy in China, we can better understand why many foreign-funded enterprises in China encountered difficulties in the progress of integration.

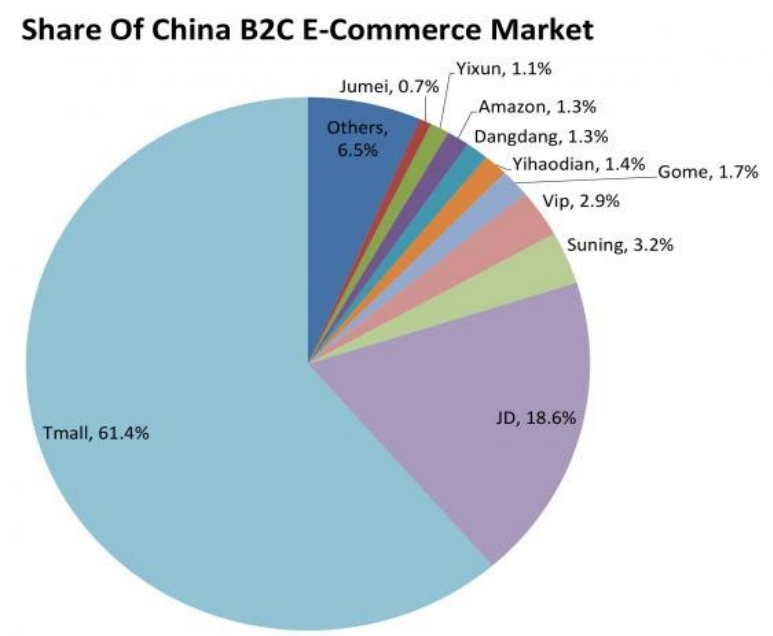

Figure 1. Share of China B2C E-commerce market in the first quarter of 2016

In recent years, the rapid development of online shopping has led to a consumer revolution, but behind the development are many problems. These issues not only greatly reduce consumer pleasure in online shopping, but also further prevent more consumers from trying and experiencing online shopping. At the same time, when the commodity and service economies mature, consumer demand gradually approaches a higher level of self-satisfaction, self-realization, and social identity (Schlegel et al., 2013). Consumer shopping behavior is not merely about the use value of goods (or functional benefits), but more importantly, to obtain a satisfactory customer experience in the shopping experience (Singh and Soch, 2015).

Nowadays, customer groups that utilize online shopping are intend to pursue a low-price, perfect personalized shopping experience. Therefore, optimizing customer experience has become an important part of electronic commerce marketing, and the details of service are directly determined by customers' online-shopping experience which means a convenient and fun, stylish experience (Yang et al., 2003).

While Amazon might always is the leader in the online shopping industry, the improvement of customer awareness of customer experience and the emergence of a large number of shopping sites have decreased Amazon's advantage. Furthermore, many problems relating to the customer experience have emerged, especially in Chinese market, which indicates a declining market share, for example, products, customer service, logistics, and processes cannot successfully adapt to Chinese market (Fan and Li, 2014). From the perspective of the consumer shopping experience, we should improve the consumer's online shopping experience by finding solutions to improve the competitiveness of the company while providing customer satisfaction and thus increasing customer loyalty (Liu and Kang, 2015).

Electronic commerce is a virtual shopping process that is linked by data information, communication services, capital flow, logistics, distribution, after-sales service, and information technology. Most of these are based on internet technology support, which is more complicated compared with the entity shop operation as each link's 
small errors will affect other aspects, which may destroy the shopping experience process (Zhang et al., 2016). Therefore, cross-border electronic commerce should aim to optimize and improve every aspect of the customer experience, from pre-sales to post-sales in the process.

\subsection{Research Objective}

Amazon China is the world's largest electronic commerce company. However, compared to other Chinese shopping sites, the Amazon customer experience is vastly different from Chinese consumers' shopping habits, which has led to poor Amazon sales (Yaobin and Tao, 2007). A study of the Amazon China customer experience design examined the development of online shopping as well as the role and impact of customer experience design in online shopping. The successful experience resulting from the customer experience design of Amazon could help other shopping sites that are still in the development stage. What's more, to improve and optimize the existing problems of Amazon, it needs to adapt to the Chinese market and understand Chinese shopping habits, so that it can achieve the same success as in other countries, thus providing customers with the perfect customer experience while improving the influence and sales volume of enterprises.

\subsection{Research Purpose}

In this project, through the study of customer experience theory, taking Amazon as an example, the design and optimization of shopping websites are examined to determine the psychological experience of customers. Electronic Commerce has spread to every part of people's lives and customer's expectations and demands of online shopping service are greater than before (Chiu et al., 2014). Therefore, the customer experience is pivotal to the website design and optimization of online shopping. The Internet has already become a part of people's lives and consumers use the Internet to buy goods more frequently. However, due to the influence of commercial interests, shopping sites appear and disappear from the Internet, and research is needed to solve the problem of the current website design and optimization (Park et al., 2012).

An increasing number of consumers notice the accuracy of online shopping information and the quality of goods, delivery, customer information security and privacy, online payment risk, reputation of the firm, customer professional knowledge, and service recovery problem (Figure 2), as these factors affect consumer online-shopping satisfaction, and even determine their future purchase behavior (Jiang et al., 2013).

\section{Consumers' Purchase Influencers When Shopping Online}

$\%$ of respondents, indicating which of the following has an influence on their purchase decisions when shopping online

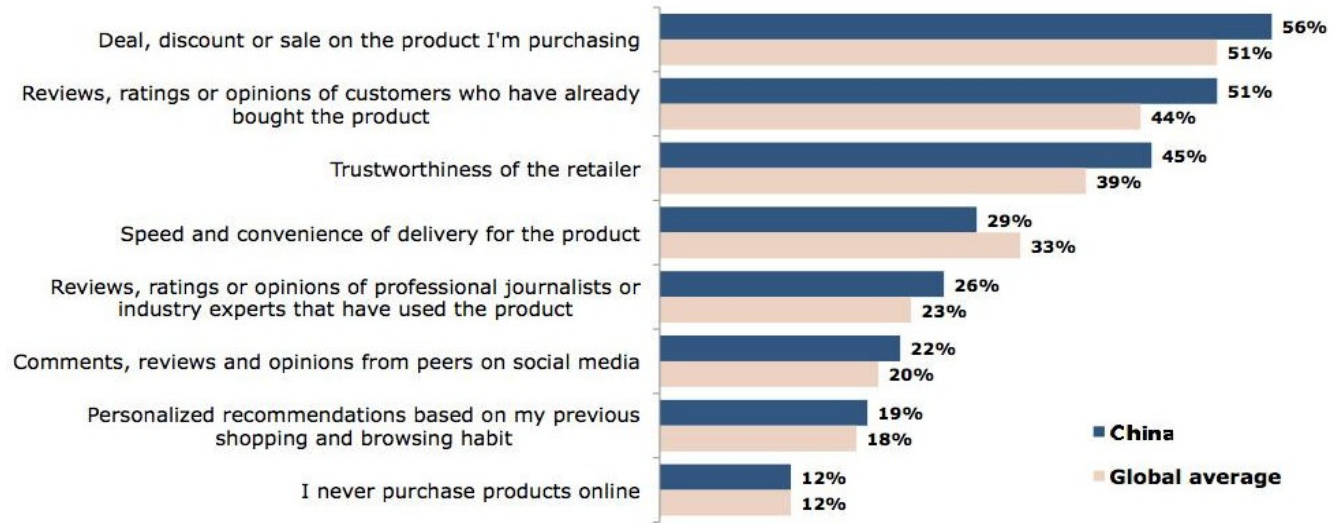

Figure 2. Consumers' purchase influences when shopping online

An enterprise should stand in the customer's position to effectively solve these problems and create value for customers, while successfully providing personalized service and satisfactory products to customers. This will improve customer satisfaction and loyalty and achieve the purpose of enterprise profit maximization (Subramanian et al., 2014).

\section{Research Review}

\subsection{The Generation of Customer Experience Design}

The arrival of economic era also changes consumers' consumption view. Economic development led to increased 
personal income, while people's lifestyle demands are also higher than before, such as diversified lifestyle and personalized consumption way (Yin, 2005). Tseng and Ho (2012) contend that simple product function and service cannot satisfy consumers' inner emotional desires. They prefer enjoyment and entertainment during the consumption process. Therefore, the product's design and the service must be based on the consumer's need. Moreover, because of the development of science and technology and the fierce market competition, if an enterprise wants to maintain its core competitiveness in the fiercely competitive market, it is necessary to pay more attention to consumer loyalty, product design and customer service to meet customer needs and enhance customer experience (Chen and Popovich, 2003).

\subsection{Customer Experience Design of Shopping Website}

The customer experience design of the shopping website is reflected in all the interaction between the customer and the shopping website. The interactive objects include watching the latest product promotion, clicking and browsing the website, viewing the help centre, advertising, mailbox, messaging and communications and even just a small label on the product page (Rahimnia and Hassanzadeh, 2013). Through study and comparison, it can be found that all of these will be connected over time, thus forming the customer's perception and experience of the shopping website. These experiences are not random, but rather a variety of data constantly generated by customer browsing behaviors and their feedback from product testing.

\subsubsection{The Importance of Customer Experience Design}

Some products will lead to a negative experience during the process of contact, for example, a shopping website design with too many options would be too complicated, as customers cannot understand how to quickly and easily make a purchase. Such enterprise should pay attention to every link, from the initial large collection of data to the analysis and design of the website. Furthermore, they must constantly adjust and optimize the website after launching it. Good user experience design of shopping online manifests that the website user interaction is changed frequently, the user viscosity increase, indirect sales increase (Richa, 2012). Rose et al. (2012) suggest that successful customer experience design for shopping website allows the website and customer to interact frequently, thus increasing the sales volume. Shopping sites that use search engines and optimize the customer experience will increase website traffic ranking in the search engine and attract a large number of visitors to the website. In the era of Internet, customer experience is increasingly becoming a key factor for the success of a product. How to provide a good customer experience to attract customers and let customers buy products should be considered by each shopping site (Yoon, 2013).

Moreover, whether the customer's experience is satisfied will directly affect the site's reputation and sales. In the similar situation of the technical conditions, companies constantly improve the experience design of the product, improve the customer experience, allow customers to feel more cheerful and more valuable, which are an effective method to build a brand and reputation (Morgan-Thomas and Veloutsou, 2013).

\subsubsection{The Significance of Customer Experience Design}

The customer experience of a shopping website mainly arises from the interaction between the customer and the computer interface. Research on the customer experience can supply the theoretical basis for future shopping website design and optimization, which will allow the shopping site to clearly understand the customer's needs and then to meet such demands (Fernie and Sparks, 2014). Good customer experience increases website page visits, makes customers decide to follow through with the purchase intention, improves consumer satisfaction and accordingly raises the credibility of the brand promotion. Consequently, the enhanced brand reputation will also convince the customer of the site's loyalty and reliability (Sirdeshmukh et al., 2002).How to make consumers receive the best customer experience by effective interaction has become the focus point of many electronic commerce sites. Customer experience is the key element of shopping website survival and the enterprise's interests. To provide customers with a satisfactory customer experience, shopping sites can attract consumers, which also lead to improved revenue for the site.

\subsubsection{The Factors That Affect the Customer Experience}

First, electronic commerce is the virtual market where goods are bought; customers cannot see the goods and they rely on text and illustrations to judge the commodities. Second, online shopping is more complex than shopping in a physical store. Thus, in online shopping, it takes a certain time interval from the purchase of goods to the delivery of customers. During this period, many factors will affect the customer's subjective feelings about the product and businesses. Last, electronic commerce's communication is dependent on the Internet, thus customer service staff needs to have excellent sales skills and services to help consumers choose the right products, promote customer buying behavior, and thus increase sales. 
Online customer service staff not only communicates with the customer to conduct the commodity trading, return and exchange. A professional customer-service staff that has knowledge and satisfactory communication skills can provide additional shopping advice to customers, as well as provide more accurate answers to customer's question, more quickly provide feedback to customer's after-sales issues, and become a customer's shopping adviser (Jie et al., 2015). Consequently, while satisfactory customer service has a great influence on the online shopping experience, customer service staff is also an important part of the online shopping experience.

\subsection{The Main Problems of Amazon China in Chinese Market}

First, Amazon China website does not have high visibility in China. However, China's commercial enterprises use a large amount of advertising and publicity, and constantly use price promotions and other marketing methods to attract customers, thereby rapidly enhancing visibility and attracting customer resources. Some Chinese consumers still view Amazon as an online book store that has nothing to do with other categories (Luo et al., 2012).

Second, customers who have used Amazon China shopping website generally report that the website design is disordered and simple, while Chinese shopping websites are more attractive with regard to visual design and are more and more neat and orderly. Furthermore, Amazon China does not behave as other local websites, which will consider local consumer habits in the shopping function, such as whether it can be online to communicate with the seller, whether it can offer the most rapid and effective after-sales answer, and whether it offers convenient and fast online payment. These problems are found on Amazon China (Clemes et al., 2014).

Third, Amazon is committed to three aspects: price, product selection, and convenient and reliable online shopping environment for consumers. However, in the Chinese market, Amazon's products are not less expensive, when consumers think of the low-price products; they will more likely consider local business platforms (Sha, 2013).

\section{Research Design and Methods}

This article adopts the secondary research method including the case study method and the textual analysis method, and they all belong to the qualitative research methodology. These methods are used to determine the influential factors of shopping site customer experience and Amazon's advantage and disadvantage in the customer experience design.

\subsection{Secondary Research}

Secondary research is the summary and integration of existing research; the data is collected from other researchers (Silverman, 2016). Since this information already exists, it can improve work efficiency and reduce the cost of research.

\subsection{Qualitative Research}

Qualitative research is used by the investigator to define and solve the problem; it is a type of research that reveals the nature of things by exploring the problem, understanding the phenomenon, and analyzing human behavior and perception. Thus, intensive research studies the characteristics and behavior of the object and investigates whether there is a relationship between them (Silverman, 2016).

\subsection{Textual Analysis Method}

Amazon is a relatively mature online shopping site, providing much material for analysis. There are a large number of studies about Amazon, so selecting the secondary research and adopting the textual analysis research method based on the past document can improve efficiency and avoid unnecessary repetition of research.

Collecting data needed with abundant reading of relevant information to understand the significance of customer experience on shopping website design and optimization. By investigating and analyzing Amazon China's website construction and customer experience through the text material and having access to Amazon website's presents customer feedback and news to collect the information and data. The comparison and analysis is then used to discover the factors affecting customer experience, and finally provides useful suggestions for developing shopping site through Amazon's strengths and successes experience.

\subsection{Case Study Analysis}

The case study is a method to conduct specific research on a single object, which can be an individual, a group, or institution.

Amazon, the world's largest shopping site, occupies most of the local market share in Europe, North America, and other places. In contrast, there is no great progress in Chinese market. Under this circumstance, adopting the 
method of case analysis to study the Major Chinese competitors' site's customer experience design, such as Interface design, function and customer service elements, take Tmall, Jingdong and other shopping sites as the example, compared with Amazon's customer experience design to found the advantage aspects and the place need to be improved. In the end, specifically analyze how to design and optimize Amazon's customer experience based on customer requirement to improve sales and expand market share (Zhang et al., 2016).

\subsection{Limitations}

As the textual analysis method and case study method belong to the secondary research, the data will face limitations of quality, authenticity, and timeliness, and if the persuasive power is not sufficient, it will lead to inadequate persuasion (Bryman and Bell, 2015). Furthermore, the information is not easy to collect. For example, some countries uphold privacy of information, which restricts the collection of data. Occasionally, the secondary date lack of purpose and focus on the research topics cannot provide a persuasive explanation, such as the sales report and the customer data that can only explain the existing customer's auxiliary data (Gerring, and 2004).

The secondary data used in the research comes from the official platform or government. It has been confirmed with effective, so the data has strong reliability and credibility (Kohlbacher, 2006).This project adopts combination of text analysis and case studies to compare a series of related resources on the basis of research, so that the results are more specific.

\section{Findings and Discussion}

In customer experience design, products must always focus on the customer. The customer experience runs through every detail. Companies' should create the product design beyond customer expectation and bring surprises to customers (Teixeira et al., 2012).

The aim of Customer experience is hoping customers will be willing to provide the feedback that accords with the enterprise's expectation through this experience, such as the purchased products, brand awareness, reputation propaganda, and customer experience is the only product factor that stimulates customer emotions (Klaus, 2013). The concept of customer experience from the entity industry to the online shopping has become a kind of new product. Value, quality, and technology are no longer the only core competitiveness of products. At the core of product, customer experience competition is the most important. Consumers' no longer just focus on product, but also enjoy the gratification and happiness brought by products (Prahalad and Ramaswamy, 2013).

When enterprises enter another country's market, localization is the core and foundation, which is the basis question all enterprises need to confront and solve, as the success of the company's localization directly affects the satisfaction of customer experience (Hasan and Hakeem, 2013). The brand's localization work involves product, design, service, marketing promotion, as well as customer operating habits.

\subsection{Web Page Design and Product Introduction}

The Amazon China website maintains the basic similar design and functions as the international website, its layout design is messier compared to the Chinese shopping site, because most Chinese sites adopt area module design, so the whole page will look orderly, such as Tmall. However, Amazon China is the natural presentation of the seller's products, regardless of the difference type and size of products. Thus, the whole page makes the customer who has adapted to the area module design feel uncomfortable with Amazon China. Moreover, in the product introduction page, all the describing information including pictures are all simple display from top to bottom, without using the layout or design to beautify the web page. This design will reduce the customer experience and cause negative psychological feelings to the Chinese consumer who cares greatly about the product packaging design.

For example, contrast in the Amazon China and Tmall's iPhone 6s product page can found the difference in the page design and layout. Tmall'siphone6s web page provides the basic information of the product, and consumers can clearly understand the product name, details, price, including supplier, and version. Above is Amazon China's website of iPhone 6s, in fact that the product introduction of the two websites is very comprehensive, including all the information. Whereas, the typesetting, color, and font on Amazon's page will make Chinese consumers feel uncomfortable, as it does not have layout design, just a simple list. When a consumer needs to spend more than six thousand Yuan to buy the product, supposing situation of price, quality, and services are the same, consumers will definitely give priority to the website that provides the better browsing experience.

\subsubsection{Simple Operation Mode}

A successful shopping site should allow customers to simply and quickly complete the operation, focus on customers, to design the clear and easy operation process to ensure that they always know how to arrive at the 
next step (Kuo and Chen, 2011). Another significant point is that it should target at customer's usage habits, when customers enter the web, where should they first pay attention to, and what is the important part. Moreover, whether customer are clicking on a purchase or viewing more items, the next step should be straightforward.

\subsubsection{Clear Structure}

In addition, maintain the website's consistency and do not make customers confused. Create a clear website structure and design a clear page information structure based on its main business wherever customers reach on a page, the site should be in just a few seconds by the screen to attract their attention and show them the main content (Bauer and Scharl, 2000). Generally, use of simple layering can create the clear structure of the website. Basing on their own business and presenting the product classification so that it provides the guidelines and highlights of the product information to customers. It is preferable to organize and display information in a corresponding pattern, because if the site structure is inconsistent with the customer's expectation or is not logical, they may be disoriented and do not know where they are going to next. This will negatively influence the customer's experience of the site, and eventually lead them to leave the site.

\subsection{Customer Service}

\subsubsection{Communication Service}

Customer service is another important impact factor in customer experience design. In China's electronic business website, consumers can communicate with retailers through specialized software such as Alitalk or other software online. This function can help consumers before they purchase products, as they could be able to obtain the answers to questions regarding the product function, quality, and after-sales service, which will help customer to know about the goods and decrease the rate of return and exchange (Choi et al., 2013). By contrast, Amazon China has not yet achieved this feature, and the common way is through emails and messages to talk about the businesses. If consumers want to counseling for goods they must rely on these methods. Because this kind of communication method has a time delay, it will make customers suspect that whether it is an efficient solution, which will, to a certain extent, hinder the consumer to purchase (Xu et al., 2015).

\subsubsection{Customer Evaluation}

Amazon does not reward buyer assessment after the purchase of commodities, so that there are few products can receive a great amount of evaluation. However, this reward system for comment is widely used on Chinese electronic business platforms, because Chinese consumers have a different consumption culture compared to Western consumers. Chinese consumers may prefer and are willing to share their own experiences. Because this shopping habit and culture are at the cultivating stage, this kind of award pattern is a better approach for consumers to have a more authentic understanding of the product from the feedback of others, not just rely on pictures.

\subsubsection{Product After-Sales Service}

Product after-sales service is an important part of customer service. Amazon China's after-sales service compared to other shopping sites is not timely enough. For example, the processing of customer feedback information and product evaluation are relatively slow, which do harm to customer experience and hinder enterprises to discover product and service problems.

Since, electronic commerce's shopping process is complex and long, the requirement of after-sales service is much higher than the physical store. After-sales service begins when the customer buys the product and completes payment. The process of waiting for the goods makes it easy for customers to change their mind. During this period, customer service needs to notify customers from every step after delivery, so that the customers can master the information in the process of every link and track their own products, thus, let customers and sellers contact more closely, and consumer can feel more caring and concern from the seller (Bauer et al., 2006).

After the customer receives the goods, the service staff should provide perfect tracking and friendly service. Customer evaluation is a vital element for customer purchase rate and product's sales volume. Other customers will refer to the evaluation when they shop on line (Zuo et al., 2013).A responsible customer service manager will daily inspect evaluations. Negative evaluations require a timely solution, which is the effective way to win consumer loyalty (Srinivasan et al., 2002).

\subsubsection{Delivery Service}

Logistics is a difficult problem for many enterprises and cannot be avoided. Amazon China's delivery service also has the insufficient aspects. For example, it does not investigate the after-sales position on time, it does not 
receive the customer's perception of the shopping experience, and thus it cannot timorously explain or remedy a problem that may occur in the process of delivery.

Enterprises can optimize the logistics system. To improve delivery efficiency and reduce the time from order to delivery, after dispatching, messages should be sent to customers to remind them to pay attention to the logistics information, which allows customers to experience the efficiency and service (Bauer et al., 2006). Furthermore, customer service should focus on the delivery information. In the case of a delivery delay or other problem, they should communicate with the post office and address the issue before it is noticed by the customer. By controlling the logistics problems, customer satisfaction will be increased (Park and Kim, 2003). Moreover, to improve the customer management system, it should automatically send a discount or sales message to customers who have not ordered for a long period or to customers with a special anniversary, which can satisfy customers' emotional needs and maintain customer loyalty.

\subsection{Marketing Promotion}

Marketing promotion can improve online shopping's popularity. In recent years, the electronic business industry developed rapidly in China, which should surpass the previous years' Amazon forecast. Moreover, in recent years, the Chinese local electronic suppliers have achieved market expansion through extensive marketing to attract Chinese consumers. However, Amazon China's marketing investment gap is larger than Chinese websites such as Tmall and Jingdong. Even in the famous enterprises list, Amazon is not near the top. Nevertheless, the real situation is that while Amazon China has maintained a low-price strategy, the commodity's price on its platform is usually lower than other shopping site's lowest price. Because of inadequate customer experience feedbacks, it cannot play its low price advantage and fail to be the first choice of people, which results in Amazon not being able to attract enough consumers.

In an era of rapid development in online shopping and due to the fierce competition, enterprises should develop a reasonable and effective promotion strategy, which not only can lead customers to know about the shopping site but also can raise the company's competition (Liu et al., 2015). For instance, sites need to adopt social media, advertising, and cooperate with the entertainment industry.

\subsection{Discussion of the Amazon's Advantage}

\subsubsection{One-Click-Ordering Function}

Amazon's one-click ordering can be learned for other online shopping companies, compared to the previous click into shopping cart, select the address, payment, and select the distribution method - a series of operation steps. The one-click function can set a fixed mode in advance on the Settings page, such as address, payment, and delivery (Sorokina and Cantu-Paz, 2016). Then, every time a consumer buys products, only one click is needed to complete the order (Figure 3). This feature can help consumers to reduce the four operating procedures. Other companies should improve their payment methods by imitating that of Amazon, which can allow customers to experience convenience, as well as increasing customer interest in the brand.
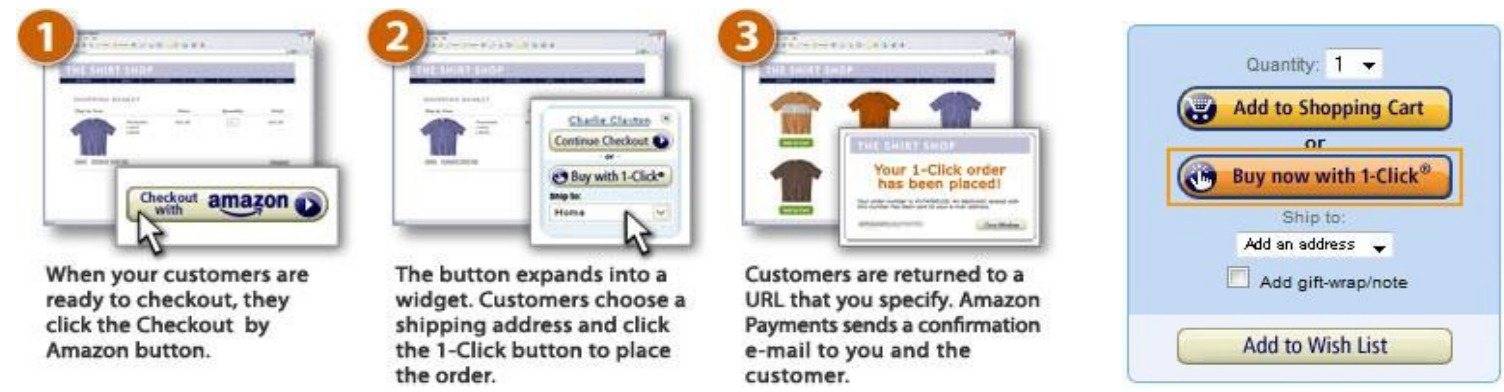

Figure 3. Amazon's one click ordering function

\subsubsection{Commodity Exchange Policy}

Whether an enterprise allows consumers to return or exchange the commodities is the basic policy of electronic business platform to service consumers. The length of time allowed to return indicates how much rights and interests consumers can receive (Wang and Le, 2015). Amazon's commodity return policy always is the best in all the businesses. That is, Amazon promises delivery within 30 days. If returned goods and their packaging stay 
the original shape when the sale of the Amazon and accessories are complete, they will provide a full refund of the service, except for some special goods (Zhang et al., 2016). However, compared to other electricity suppliers, such as Tmall, Jingdong, their commodity return policy is not as good as Amazon's.

\subsubsection{Customization Service}

Another Amazon feature is the individualization recommendation system. For example, when a customer types a commodity name in the search engine and view it, Amazon will automatically record the consumer's preference, and then create a recommendation list, which includes recently viewed commodities and similar products. These functions ensure consumers to quickly find the goods they need and rapidly receive the relevant information. This useful function saves customers' time and increases efficiency thus improving customer experience (Zhao et al., 2015).

\section{Conclusions}

This article uses secondary research, including the textual analysis method and the case study method, which all belong to the qualitative research method. First, through the textual analysis, much relevant information is collected. The article then makes a simple theory review of the basic concept of customer experience design, background, and characteristics, and introduces the concept of online shopping, patterns, and the effect in the customer experience design. Second, the adopted case study method combined with the information obtained from the textual analysis to investigate Amazon China demonstrated that Amazon is the world's largest B2C electronic business platform with the advanced technical capability and rich experience in operations management. Therefore, this project selected Amazon China as the research object. Amazon's successful experience can provide valuable advice for many developing shopping websites.

However, Amazon China in the Chinese market is unlike other countries that occupied most of the market share. After analysis of Amazon China's current development situation, from the view of customer experience and to compare the difference between Amazon China and its main competitor in the Chinese market in product, design, service, and marketing. Then, discovering the aspects that Amazon China needs to concern and strengthen the customer experience, the optimization advice has an important impact on Amazon China's marketing strategy adjustment.

Amazon China, because of a lack of localization ability, timely customer service and marketing promotion, which made it develop relatively slowing the Chinese market, and its market share also decreased due to the competitor's fast growth and optimization (Zeng and Glaister, 2015). Therefore, enterprises require effective adjustment and improve Amazon China's customer experience, in the web interface design, it needs to adapt to the target customers' visual habits (Luo et al., 2012). In the customer service, the aim is to provide customers with the most satisfactory customer experience, to expand the range of service, communicate timely and improve the rate of feedback (Jiang et al., 2013). In the after-sales service, handling problems in time will let customer know the specific delivery information. In the marketing promotion, expand the advertising effect, and frequently use social media and other new publicity methods. Finally, by maintaining Amazon's original strengths, optimizing and improving the weak links, Amazon can improve the quality of customer experience, gain greater customer trust, and increase its ability to occupy a larger market share. In this way, Amazon China can develop better in the Chinese market and supply a high quality customer experience and service to every consumer.

\section{References}

Ahmed, S., \& Rahman, M. (2015). The Effects of Marketing Mix on Consumer Satisfaction: A Literature Review from Islamic Perspective. Turkish Journal of Islamic Economics, 2(1), 17-30. https://doi.org/10.15238/tujise.2015.2.1.17-30

Ali, F., Kim, W. G., Li, J., \& Jeon, H. M. (2016). Make it delightful: Customers' experience, satisfaction and loyalty in Malaysian theme parks. Journal of Destination Marketing \& Management, 1-11. https://doi.org/10.1016/j.jdmm.2016.05.003

Amblee, N., \& Bui, T. (2011). Harnessing the influence of social proof in online shopping: The effect of electronic word of mouth on sales of digital microproducts. International Journal of Electronic Commerce, 16(2), 91-114. https://doi.org/10.2753/JEC1086-4415160205

Bauer, C., \& Scharl, A. (2000). Quantitive evaluation of Web site content and structure. Internet Research, 10(1), 31-44. https://doi.org/10.1108/10662240010312138

Bauer, H. H., Falk, T., \& Hammerschmidt, M. (2006). eTransQual: A transaction process-based approach for 
capturing service quality in online shopping. Journal of Business Research, 59(7), 866-875. https://doi.org/10.1016/j.jbusres.2006.01.021

Bilgihan, A., Kandampully, J., \& Zhang, T. (2016). Towards a unified customer experience in online shopping environments: Antecedents and outcomes. International Journal of Quality and Service Sciences, 8(1), 102-119. https://doi.org/10.1108/IJQSS-07-2015-0054

Bryman, A., \& Bell, E. (2015). Business research methods. Oxford University Press, USA.Carley, K. (1993). Coding choices for textual analysis: A comparison of content analysis and map analysis. Sociological Methodology, 75-126. https://doi.org/10.2307/271007

Chen, I. J., \& Popovich, K. (2003). Understanding customer relationship management (CRM) People, process and technology. Business Process Management Journal, 9(5), 672-688. https://doi.org/10.1108/14637150310496758

Chiu, C. M., Wang, E. T., Fang, Y. H., \& Huang, H. Y. (2014). Understanding customers' repeat purchase intentions in $\mathrm{B} 2 \mathrm{C}$ e- commerce: the roles of utilitarian value, hedonic value and perceived risk. Information Systems Journal, 24(1), 85-114. https://doi.org/10.1111/j.1365-2575.2012.00407.x

Choi, T. M., Chow, P. S., Kwok, B., Liu, S. C., \& Shen, B. (2013). Service quality of online shopping platforms: a case-based empirical and analytical study. Mathematical Problems in Engineering, 2013, 1-9. https://doi.org/10.1155/2013/128678

Clemes, M. D., Gan, C., \& Zhang, J. (2014). An empirical analysis of online shopping adoption in Beijing, China. Journal of Retailing and Consumer Services, 21(3), 364-375. https://doi.org/10.1016/j.jretconser.2013.08.003

Fan, R., \& Li, Y. (2014). The coordination of E-commerce and Logistics: A case study of Amazon. Com, 1-51.

Fernie, J., \& Sparks, L. (2014). Logistics and retail management: emerging issues and new challenges in the retail supply chain. Kogan Page Publishers.

Froehle, C. M. (2006). Service personnel, technology, and their interaction in influencing customer satisfaction. Decision Sciences, 37(1), 5-38. https://doi.org/10.1111/j.1540-5414.2006.00108.x

Frow, P., \& Payne, A. (2007). Towards the 'perfect'customer experience. Journal of Brand Management, 15(2), 89-101. https://doi.org/10.1057/palgrave.bm.2550120

Gandhi, S. K. (2016). India's Jumbo Jump from E-Commerce to Mobile Enabled Services (MES): A Review. Productivity, 56(4), 326.

Gentile, C., Spiller, N., \& Noci, G. (2007). How to sustain the customer experience: An overview of experience components that co-create value with the customer. European Management Journal, 25(5), 395-410. https://doi.org/10.1016/j.emj.2007.08.005

Gerring, J. (2004). What is a case study and what is it good for?. American Political Science Review, 98(2), 341-354. https://doi.org/10.1017/S0003055404001182

Ha, H. Y., \& Perks, H. (2005). Effects of consumer perceptions of brand experience on the web: Brand familiarity, satisfaction and brand trust. Journal of Consumer Behaviors, 4(6), 438-452. https://doi.org/10.1002/cb.29

Hasan, M. N., \& Hakeem, G. (2013). To Standardize or to Adapt: A Website's Dilemma in the Context of Online Customersatisfaction: A Comparative Study of Unilever \& Adhuli Website's in the Bangladeshi Market, 1-109.

Havinga, M., Hoving, M., \& Swagemakers, V. (2016). Alibaba: A Case Study on Building an International Imperium on Information and E-Commerce. Multinational Management, 13-32. https://doi.org/10.1007/978-3-319-23012-2_2

Janita, M. S., \& Miranda, F. J. (2013). Exploring service quality dimensions in b2b e-marketplaces. Journal of Electronic Commerce Research, 14(4), 363-386.

Javadi, M. H. M., Dolatabadi, H. R., Nourbakhsh, M., Poursaeedi, A., \& Asadollahi, A. R. (2012). An analysis of factors affecting on online shoppingbehavior of consumers. International Journal of Marketing Studies, 4(5), 81-98. https://doi.org/10.5539/ijms.v4n5p81

Jiang, L., Yang, Z., \& Jun, M. (2013). Measuring consumer perceptions of online shopping convenience. Journal of Service Management, 24(2), 191-214. https://doi.org/10.1108/09564231311323962 
Jie, Y. U., Subramanian, N., Ning, K., \& Edwards, D. (2015). Product delivery service provider selection and customer satisfaction in the era of internet of things: a Chinese e-retailers' perspective. International Journal of Production Economics, 104-116. https://doi.org/10.1016/j.ijpe.2014.09.031

Kacen, J. J., Hess, J. D., \& Chiang, W. Y. K. (2013). Bricks or clicks? Consumer attitudes toward traditional stores and online stores. Global Economics and Management Review, 18(1), 12-21. https://doi.org/10.1016/S2340-1540(13)70003-3

Kim, C., Zhao, W., \& Yang, K. H. (2008). An empirical study on the integrated framework of e-CRM in online shopping: evaluating the relationships among perceived value, satisfaction, and trust based on customers' perspectives. Journal of Electronic Commerce in Organizations, 6(3), 1-19. https://doi.org/10.4018/jeco.2008070101

Kim, J., \& Lennon, S. J. (2013). Effects of reputation and website quality on online consumers' emotion, perceived risk and purchase intention: Based on the stimulus-organism-response model. Journal of Research in Interactive Marketing, 7(1), 33-56. https://doi.org/10.1108/17505931311316734

Klaus, P. (2013). The case of Amazon.com: towards a conceptual framework of online customer service experience (OCSE) using the emerging consensus technique (ECT). Journal of Services Marketing, 27(6), 443-457. https://doi.org/10.1108/JSM-02-2012-0030

Kohlbacher, F. (2006). The use of qualitative content analysis in case study research. In Forum Qualitative Social for schung /Forum: Qualitative Social Research, 7(1), 1-30.

Kuo, H. M., \& Chen, C. W. (2011). Application of quality function deployment to improve the quality of Internet shopping website interface design. International Journal of Innovative Computing, Information and Control, 7(1), 253-268.

Laudon, K. C., \& Traver, C. G. (2009). E-commerce business models and concepts. sl: Prentice Hall, a divison of Pearson Education, Inc, pp.63-115.

Li, J., Ji, H., Qi, L., Li, M., \& Wang, D. (2015). Empirical Study on Influence Factors of Adaption Intention of Online Customized Marketing System in China. International Journal of Multimedia and Ubiquitous Engineering, 10(6), 365-378. https://doi.org/10.14257/ijmue.2015.10.6.35

Liu, Y., \& Kang, T. (2015). Operational Model of China's Express Services Industry: A Case Study of SF-Express. Journal of International Trade \& Commerce, 11(5), 43-58. https://doi.org/10.16980/jitc.11.5.201510.43

Liu, Y., Li, H., Peng, G., Lv, B., \& Zhang, C. (2015). Online purchaser segmentation and promotion strategy selection: evidence from Chinese E-commerce market. Annals of Operations Research, 233(1), 263-279. https://doi.org/10.1007/s10479-013-1443-Z

Luo, J., Ba, S., \& Zhang, H. (2012). The effectiveness of online shopping characteristics and well-designed websites on satisfaction. Mis Quarterly, 36(4), 1131-1144. https://doi.org/10.2307/41703501

Mangiaracina, R., Marchet, G., Perotti, S., \& Tumino, A. (2015). A review of the environmental implications of B2C e-commerce: a logistics perspective. International Journal of Physical Distribution \& Logistics Management, 45(6), 565-591. https://doi.org/10.1108/IJPDLM-06-2014-0133

Menon, S., \& Kahn, B. (2002). Cross-category effects of induced arousal and pleasure on the Internet shopping experience. Journal of Retailing, 78(1), 31-40. https://doi.org/10.1016/S0022-4359(01)00064-1

Morgan-Thomas, A., \& Veloutsou, C. (2013). Beyond technology acceptance: Brand relationships and online brand experience. Journal of Business Research, 66(1), 21-27. https://doi.org/10.1016/j.jbusres.2011.07.019

Myers, R. H., Montgomery, D. C., \& Anderson-Cook, C. M. (2016). Response surface methodology: process and product optimization using designed experiments. John Wiley \& Sons.

Park, C. H., \& Kim, Y. G. (2003). Identifying key factors affecting consumer purchase behavior in an online shopping context. International Journal of Retail \& Distribution Management, 31(1), 16-29. https://doi.org/10.1108/09590550310457818

Park, C., \& Kim, Y. (2008). The Effect of Information Satisfaction and Relational Benefit on Consumer's Online Shopping Site Commitment. Web Technologies for Commerce and Services Online, 1-149. https://doi.org/10.4018/978-1-59904-822-2.ch009

Park, E. J., Kim, E. Y., Funches, V. M., \& Foxx, W. (2012). Apparel product attributes, web browsing, and 
e-impulse buying on shopping websites. Journal of Business Research, 65(11), 1583-1589. https://doi.org/10.1016/j.jbusres.2011.02.043

Perzanowski, A., \& Hoofnagle, C. J. (2016). What We Buy When We" Buy Now". University of Pennsylvania Law Review, 1-60. https://doi.org/10.31228/osf.io/kw7sx

Prahalad, C. K., \& Ramaswamy, V. (2013). The future of competition: Co-creating unique value with customers. Harvard Business Press.

Rahimnia, F., \& Hassanzadeh, J. F. (2013). The impact of website content dimension and e-trust on e-marketing effectiveness: The case of Iranian commercial saffron corporations. Information \& Management, 50(5), 240-247. https://doi.org/10.1016/j.im.2013.04.003

Ribbink, D., Van Riel, A. C., Liljander, V., \& Streukens, S. (2004). Comfort your online customer: quality, trust and loyalty on the internet. Managing Service Quality: An International Journal, 14(6), 446-456. https://doi.org/10.1108/09604520410569784

Richa, D. (2012). Impact of demographic factors of consumers on online shopping behaviour: A study of consumers in India. International Journal of Engineering and Management Sciences, 3(1), 43-52.

Roberts, M., Xu, X. M., \& Mettos, N. (2003). Internet shopping: the supermarket model and customer perceptions. Journal of Electronic Commerce in Organizations (JECO), 1(2), 32-43. https://doi.org/10.4018/jeco.2003040103

Rose, S., Clark, M., Samouel, P., \& Hair, N. (2012). Online customer experience in e-retailing: an empirical model of antecedents and outcomes. Journal of Retailing, 88(2), 308-322. https://doi.org/10.1016/j.jretai.2012.03.001

Rust, R. T., \& Kannan, P. K. (2003). E-service: a new paradigm for business in the electronic environment. Communications of the ACM, 46(6), 36-42. https://doi.org/10.1145/777313.777336

Schlegel, R. J., Hicks, J. A., Davis, W. E., Hirsch, K. A., \& Smith, C. M. (2013). The dynamic interplay between perceived true self-knowledge and decision satisfaction. Journal of Personality and Social Psychology, 104(3), 542-558. https://doi.org/10.1037/a0031183

Sha, K. (2013). Trends and issues related to online shopping market in China. In 2013 6th International Conference on Information Management, Innovation Management and Industrial Engineering, 183-187. https://doi.org/10.1109/ICIII.2013.6703114

Silverman, D. (2016). Qualitative research. Sage.

Singh, P., \& Soch, H. (2015). Examining Mediating Effects of Customer Shopping Experience on the Relationship between Antecedents of In-Store Experience and Impulse Buying-A Theoretical Framework. International Proceedings of Economics Development and Research, 39-48.

Sirdeshmukh, D., Singh, J., \& Sabol, B. (2002). Consumer trust, value, and loyalty in relational exchanges. Journal of Marketing, 66(1), 15-37. https://doi.org/10.1509/jmkg.66.1.15.18449

Sorokina, D., \& Cantu-Paz, E. (2016). Amazon Search: The Joy of Ranking Products. In Proceedings of the 39th International ACM SIGIR conference on Research and Development in Information Retrieval, 459-460. https://doi.org/10.1145/2911451.2926725

Srinivasan, S. S., Anderson, R., \& Ponnavolu, K. (2002). Customer loyalty in e-commerce: an exploration of its antecedents and consequences. Journal of Retailing, 78(1), 41-50. https://doi.org/10.1016/S0022-4359(01)00065-3

Subramanian, N., Gunasekaran, A., Yu, J., Cheng, J., \& Ning, K. (2014). Customer satisfaction and competitiveness in the Chinese E-retailing: Structural equation modeling (SEM) approach to identify the role of quality factors. Expert Systems with Applications, 41(1), 69-80. https://doi.org/10.1016/j.eswa.2013.07.012

Teixeira, J., Patrício, L., Nunes, N. J., Nóbrega, L., Fisk, R. P., \& Constantine, L. (2012). Customer experience modeling: from customer experience to service design. Journal of Service Management, 23(3), 362-376. https://doi.org/10.1108/09564231211248453

Tseng, Y. S., \& Ho, M. C. (2012). Creating sustainable emotional value through personalized design. In Design for Innovative Value Towards a Sustainable Society, 257-260. https://doi.org/10.1007/978-94-007-3010-6_49 
Wang, L. W., \& Le, Q. L. (2015). Customer Satisfaction towards Online Shopping at Electronics Shopping Malls in Vietnam-A Conceptual Model to Enhance Business Success through Efficient Websites and Logistics Services. Journal of Stock \& Forex Trading, 5(1), 1-10.

Wang, T. L., Lin, H. P., \& Sung, Y. C. (2016). Remaining As A Leader or Not? Technology Spillover Answers. Applied Economics and Finance, 3(2), 110-121. https://doi.org/10.11114/aef.v3i2.1357

Wang, X. (2012). Foreign direct investment and innovation in China's e-commerce sector. Journal of Asian Economics, 23(3), 288-301. https://doi.org/10.1016/j.asieco.2010.11.007

Xu, H., Liu, D., Wang, H., \& Stavrou, A. (2015). E-commerce reputation manipulation: The emergence ofreputation-escalation-as-a-service. In Proceedings of the 24th International Conference on World Wide Web, 1296-1306. https://doi.org/10.1145/2736277.2741650

Yang, Z., Peterson, R. T., \& Cai, S. (2003). Services quality dimensions of Internet retailing: An exploratory analysis. Journal of Services Marketing, 17(7), 685-700. https://doi.org/10.1108/08876040310501241

Yaobin, L., \& Tao, Z. (2007). A research of consumers' initial trust in online stores in China. Journal of Research and Practice in Information Technology, 39(3), 167-180.

Yin, X. (2005). New trends of leisure consumption in China. Journal of Family and Economic Issues, 26(1), 175-182. https://doi.org/10.1007/s10834-004-1419-x

Yoon, V. Y., Hostler, R. E., Guo, Z., \& Guimaraes, T. (2013). Assessing the moderating effect of consumer product knowledge and online shopping experience on using recommendation agents for customer loyalty. Decision Support Systems, 55(4), 883-893. https://doi.org/10.1016/j.dss.2012.12.024

Zeng, J., \& Glaister, K. W. (2015). Competitive dynamics between multinational enterprises and local internet platform companies in the virtual market in China. British Journal of Management, 479-496. https://doi.org/10.1111/1467-8551.12136

Zhang, S., Wang, H., \& Huang, M. (2016). Research of E-commerce logistics based on the network information era. In 2016 Chinese Control and Decision Conference (CCDC), 6014-6019. https://doi.org/10.1109/CCDC.2016.7532075

Zhao, Q., Zhang, Y., Friedman, D., \& Tan, F. (2015). E-commerce Recommendation with Personalized Promotion. In Proceedings of the 9th ACM Conference on Recommender Systems, 219-226. https://doi.org/10.1145/2792838.2800178

Zuo, W., Huang, Q., Fan, C., \& Zhang, Z. (2013). Quality management of B2C e-commerce service based on human factors engineering. Electronic Commerce Research and Applications, 12(5), 309-320. https://doi.org/10.1016/j.elerap.2013.03.005

\section{Copyrights}

Copyright for this article is retained by the author(s), with first publication rights granted to the journal.

This is an open-access article distributed under the terms and conditions of the Creative Commons Attribution license (http://creativecommons.org/licenses/by/4.0/). 